\title{
Histology of juvenile African giant catfish (Clarias gariepinus) fed Morinda lucida
}

\section{(Oruwo leaf)}

*Raimi, C. O., Oyelade, W. A. and Alao, A. O.

Department of Agriculture, Federal Polytechnic, P.M.B.5351, Ado-Ekiti

Department of Biological Science, Federal Polytechnic, P.M.B.5351, Ado-

Abstract

Ekiti

Medicinal plants have been widely accepted as feed additives to enhance feed utilization and aquaculture production performance and sustainability. Expensive feeds have marginalized or even nullify the profitability of fish farming production, consequently lowering yield in terms of quality and quantity. Acute toxicity tests using aqueous extracts of Morindalucida on juvenile Clariasgariepinuswere conducted in a static bioassay inside plastic tanks for 8 weeks feeding trial. They were fed five dietary treatments of $0 \%$ (controls), 25\%, 50\%, 75\% and $100 \%$ Morinda inclusion and each treatment was replicated thrice. For each test, 10 juveniles Clariasgariepinuswere used in each plastic tank. The responses exhibited by the fishsubjected to the toxicant include erratic swimming, loss of reflex, colour change, weakened motion and vertical swimming. These were enhanced by the increase in concentration of the toxicant and the duration of exposure. Significant $(P<0.05)$ higher mortality was recorded in fish fed with T5 (100\% Morindalucida) inclusion. Histological changes occurred in the gills and liver of the fish in the definitive test as gill alterations (hydropic degeneration of the gill rays, degeneration of the gill lamellae and necrosis) which were usually related to gills function disorders. Liver shows hepato-cellular architecture, hydropic degeneration, vacuolation of the liver cells and spaces within the cell protoplasm filled with fluid.

Keywords: Juvenile Clariasgariepinus,Histology, Liver, Gills, Small intestine, Morindalucida

\section{Histologie de juvéniles de poisson-chat géant africain (Clarias gariepinus) nourris de Morindalucida (feuille d'Oruwo)}

\section{Résumé}

Les plantes médicinales ont été largement acceptées comme additifs alimentaires pour améliorer l'utilisation des aliments et les performances et la durabilité de la production aquacole. Les aliments coûteux ont marginalisé voire anéanti la rentabilité de la production piscicole, diminuant par conséquent les rendements en termes de qualité et de quantité. Des tests de toxicité aiguë utilisant des extraits aqueux de Morindalucida sur des jeunes Clarias gariepinus ont été menés dans un essai biologique statique à l'intérieur de réservoirs en plastique pendant 8 semaines d'essai d'alimentation. Ils ont reçu cinq traitements diététiques de $0 \%$ (témoins), $25 \%, 50 \%, 75 \%$ et $100 \%$ d'inclusion de Morinda et chaque traitement a été répété trois fois. Pour chaque test, 10 juvéniles de Clarias gariepinus ont été utilisés dans chaque bac en plastique. Les réponses présentées par les poissons soumis à la substance toxique comprennent une nage erratique, une perte de réflexe, un changement de couleur, un mouvement affaibli et une nage verticale. Celles-ci ont été renforcées par l'augmentation de la concentration du toxique et de la durée d'exposition. Une mortalité significativement plus élevée $(P<0,05)$ a été enregistrée chez les poissons nourris avec une inclusion de T5 $(100 \%$ Morindalucida). Des modifications histologiques se sont produites dans les branchies et le 


\section{Histology of juvenile African giant catfish (Clarias gariepinus)}

foie des poissons dans le test définitif sous forme d'altérations des branchies (dégénérescence hydropique des rayons branchiaux, dégénérescence des lamelles branchiales et nécrose) qui étaient généralement liées à des troubles de la fonction branchiale. Le foie montre une architecture hépato-cellulaire, une dégénérescence hydropique, une vacuolisation des cellules hépatiques et des espaces dans le protoplasme cellulaire remplis de liquide.

Mots clés : Juvénile Clarias gariepinus, Histologie, Foie, Branchies, Intestin grêle, Morindalucida

\section{Introduction}

Diet supplementation is an important aspect in aquaculture management especially in intensive or semi-intensive fish culture and it is promising for increasing fish production. El-Haroun (2007) pointed out that diet is often the single largest item that represent over $50 \%$ of the operating costs in intensive aquaculture. Induced breeding has been introduced and widely used throughout Nigeria to increase the production of farm raised catfish (Adewumi and Olaleye, 2010). Currently, natural materials (medical plants) such as bitter leaf, scent leaf, bitter kola have been widely accepted as feed additives to enhance feed utilization and aquaculture production performance and sustainability (Levicet al., 2008). Expensive feeds have marginalized or even nullify the profitability of fish farming production, consequently lowering yield in terms of quality and quantity. Kidney, liver, gills played a vital role in the maintenance of an organism internal environment being the key to the regulation of volume of extracellular fluid and composition as well as acid base balance. The toxic chemical target to the internal organs and disrupt its functions and cause temporary or permanent rearrangement of homeostasis (Miller et al., 2002). Poisonous plants are known to cause decrease in dissolved oxygen and physiological changes in the fish which eventually leads to the death of aquatic life (Morahet al., 2005). The kidney for example, is a vital organ playing a crucial role in the elimination of metabolic nitrogen waste, maintenance of homeostasis and synthesis of essential hormones. Owing to significant blood flow circulating through kidney tissues, and large amount of toxin afflux, the kidney is the primary toxicant target organ (Oduolaet al., 2010). Hence exposure to environmental pollutants increases the risk of kidney disease. As evidenced by failure of certain organ processes following the accumulation of toxicants in the nephron and particularly in the renal tubules. When the concentration of the toxic substance is higher than what the homeostasis of the aquatic organism can control, it results in organ damages. In fish, organs such as opercular, the skin, liver, small intestine and gills could be impaired (Oyedapo, 2011). The effects of waste water discharged into water bodies can be acute that is occurs rapidly and are clearly defined as fatal and rarely reversible or chronic which normally have lingering effects after long period of exposure and may ultimately cause death (Adewoye, 2005). The need to enhance growth performance on feed efficiency and disease resistance of cultured organism is substantial for various sectors of this industry (El- Harounet al., 2006). The knowledge that harmful compounds elicit both toxic and advantageous biological responses has given rise to several investigations in recent times as to their possible physiological implications in various biological systems. Toxicity is expressed generally as a dose-response relationship, involving the quantity of substance to which the organism is exposed to. Furthermore, it is well known that many plant products contain some toxic substances which when consumed could accumulate gradually in the body and later 


\section{Raimi, Oyelade and Alao}

cause some damages to cells, tissue or organs. The toxic effects of environmental toxins and drugs on the human and animal system have become a major health concern (Nawal, 2015). It is noteworthy that Morindalucidaleaves have not been used as a phytobiotics in fish species. Hence, this study aims at determining histology of juvenile Clariasgariepinus fed different concentrations of Morinda lucida leaves.

\section{Materials and methods \\ Experimental site}

An eight weeks feeding trial was conducted at the site of Agricultural Technology Department, Federal Polytechnic, AdoEkiti, Ekiti State, Nigeria. The state is located in south western part of the country, Ekiti State covers a land area of $6,353 \mathrm{~km}$ square (2453sqmi) with a population estimated in 2005 to be $2,737,186$. It enjoys tropical climate with two distinct seasons, these are rainy season (April to October) and dry season (November to March). AdoEkiti has a temperature ranges between 21 degrees Celsius and 28 degrees Celsius with high humidity, the Southwesterly wind and the North east trade which blows in the raining season and dry (harmattan) season respectively, the tropical forest exist in the south of Ekiti State while savannah occupies the northern peripheries.

\section{Experimental design}

One hundred and fifty juvenile fish (150)

African giant catfish were acquired from a reputable farm, the fish was acclimatized in 60L experimental plastic tanks $(1 \times 1 \times 0.2 \mathrm{~m})$ labelled as T1, T2, T3, T4 and T5

$$
\begin{aligned}
& \mathrm{T} 1=0 \% \text { control } \\
& \mathrm{T} 2=25 \% \text { mixture of leaf meal } \\
& \mathrm{T} 3=50 \% \text { mixture of leaf meal } \\
& \mathrm{T} 4=75 \% \text { mixture of leaf meal } \\
& \mathrm{T} 5=100 \% \text { mixture of leaf meal }
\end{aligned}
$$

Each treatment consisted of (10) juvenile catfish and replicated three times in a complete randomized design (CRD).

\section{Experimental procedure Experimental animals}

The fishes were acclimatized for seven days and the initial body weights of 150 juveniles of $C$. gariepinus were measured and recorded, the fishes were transferred into each of the plastic tanks using a scoop net. Suitable conditions were maintained by cleaning the containers and constant changing of the water was done every three days.

\section{Morinda lucida preparation}

The Morinda Lucida leaves were rinsed with distilled water, dried in air for 3days and powdered. The feed was pelleted into $2 \mathrm{~mm}$ pellet size for a period of 12 weeks ( 84 days). The formulated feeds were given at a $5 \%$ body weight of the fish twice daily till the end of the feeding trials. At the end of the study, histological examination of the gills, livers, and kidney were examined on Clariasgariepinus fed Morinda lucida

\section{Dissection of fish}

At the end of the experiment, all the fishes were sacrificed, the liver and gonads were removed liver was excised using scissors and forceps and weighed to determine the hepatosomatic index and gonad somatic index as describe as the method of Tseng (1982).

\section{Histopathological analysis}

$1 \mathrm{~g}$ of each organ was put in $10 \mathrm{ml}$ of formal saline for proper fixation, and after the tissues have been processed and embedded in paraffin wax, sections of about $5 \mu \mathrm{m}-6$ $\mu \mathrm{m}$ thick were made and stained with haematoxylin and eosin for histopathological examination (Avwioro, 2010).

\section{Grossing}

The tissues were observed and cut into small pieces of not more than $4 \mathrm{~mm}$ thick into pre-labeled cassettes. These were further immersed in $10 \%$ formal saline for 24 hours to fix.

\section{Tissue processing}

This was done automatically using 


\section{Histology of juvenile African giant catfish (Clarias gariepinus)}

automatic tissue processor (Leica TP 1020). The tissues were allowed to pass through various reagents including; stations 1 and 2 containing $10 \%$ formal saline, station 3 to station 7 ; alcohol $(70 \%, 80 \%, 90 \%, 95 \%$, absolute 1 and absolute 11) for the purpose of dehydration. The tissues continued to pass through station 8 and station 9 containing two changes of xylene for the purpose of clearing and finally transferred into three wax baths for infiltration/impregnation. The machine has been programmed to run for 12 hours; tissues stayed in each station for 1 hour.

\section{Embedding}

Eachprocessed tissue was given a solid support medium (paraffin wax) and this was done using a semi-automatic tissue embedding center. The molten paraffin wax was dispensed into a metal mold and the tissue was buried and oriented in it, a prelabeled cassette was placed on this and was transferred to a cold plate to solidify. The tissue block formed was separated from the mold.

\section{Microtomy}

The blocks were trimmed to expose the tissue surface using a rotary microtome at 6 micrometer. The surfaces were allowed to cool on ice before sectioning. The tissues were sectioned at 4 micrometer (ribbon section)

\section{Floating}

The sections were floated on water bath (Raymond lamb) set at $55^{\circ} \mathrm{C}$ and these were picked using clean slides. The slides were labeled.

\section{Drying}

The slides were dried on a hotplate
(Raymond lamb) set at $60^{\circ} \mathrm{c}$ for 1 hour.

\section{Staining}

The staining technique used was Haematoxylin and Eosin technique

\section{Results}

Figure 1 represents photomicrograph of a fish liver section stained by Haematoxylin and Eosin, showing normal venule without congestion (white arrow), the liver hepatocytes show normal glycogen infiltration (slender arrow), the sinusoid appear normal and not infiltrated.Fragment of the liver tissue showing normal venule without congestion (white arrow), the liver hepatocytes show moderate fat and glycogen infiltration (slender arrow), the sinusoid appear normal and not infiltrated (Figure 2). Figure 3 reveals venule with mild congestion (white arrow), and moderate peri vascular infiltration of inflammatory cells (black arrow), the liver hepatocytes show moderate fat and glycogen infiltration (slender arrow), the sinusoid appear normal and not infiltrated. There were normal venules without congestion (white arrow), the liver parenchyma shows area of somewhat fatty degeneration and necrosis (black arrow) hepatocytes show moderate fat and glycogen infiltration (slender arrow), the sinusoid appears normal and not infiltrated (Figure 4). Finally, Figure 5 shows normal uncongested venule (white arrow), the liver hepatocytes show focal area of mild degeneration (black arrow), most of the hepatocyte's cytoplasm appear vacuolated which is probably as a result of glycogen filling (slender arrow) 


\section{Raimi,Oyelade and Alao}
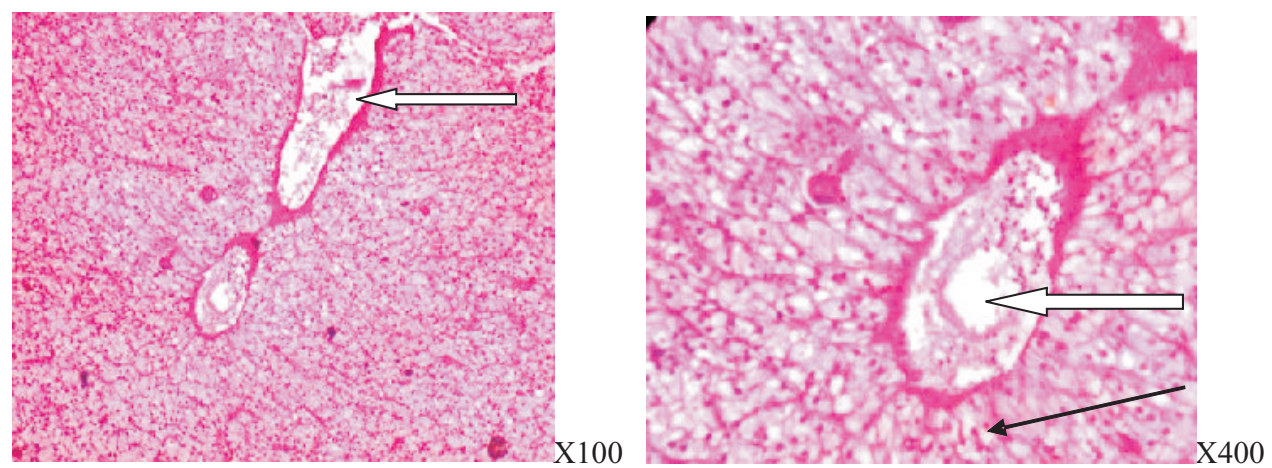

Figure 1: Histological section of liver of fish fed with control diet
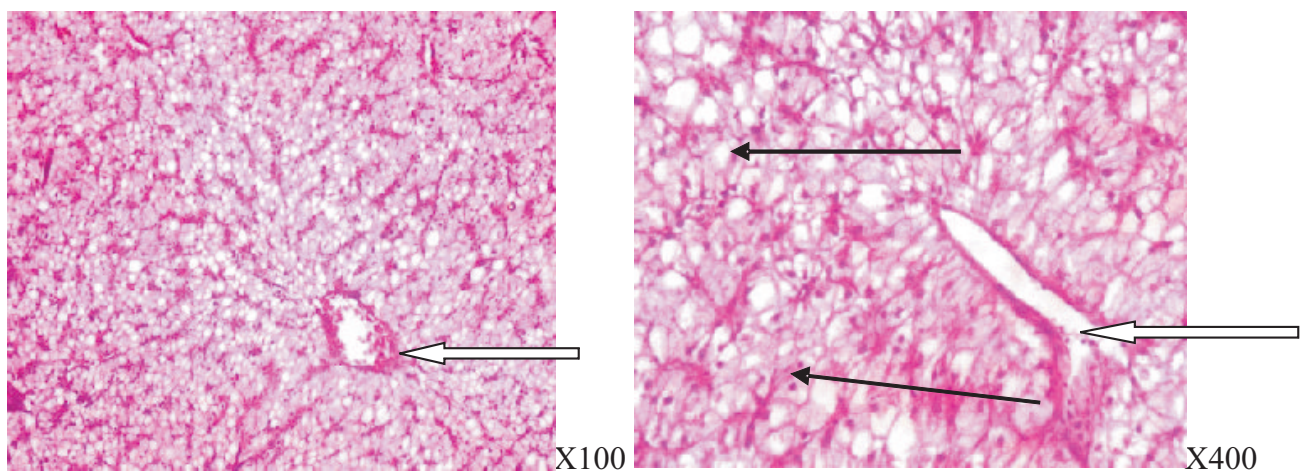

Figure 2: Histological section of liver of fish fed 25\% Morinda lucidaleaves
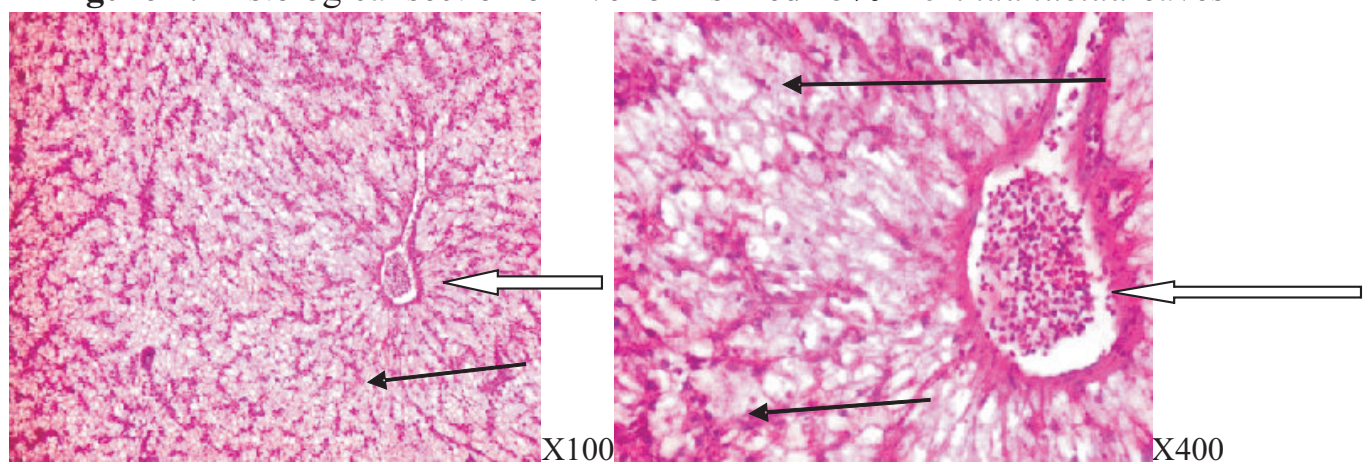

Figure 3: Histological section of liver of fish fed 50\% Morinda lucida leaves
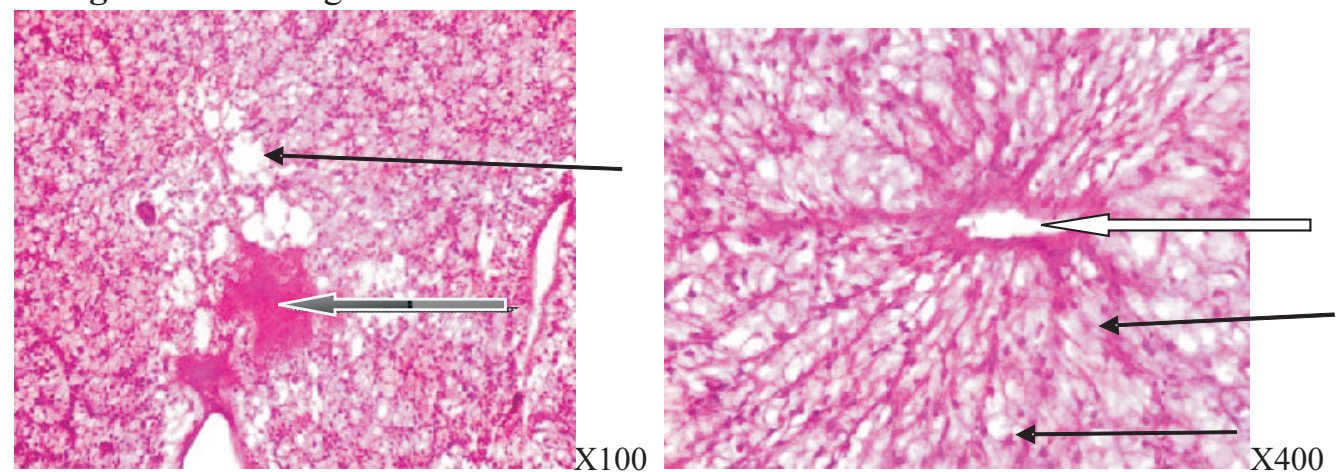

Figure 4: Histological section of liver of fish fed 75\% Morinda lucida leaves 


\section{Histology of juvenile African giant catfish (Clarias gariepinus)}
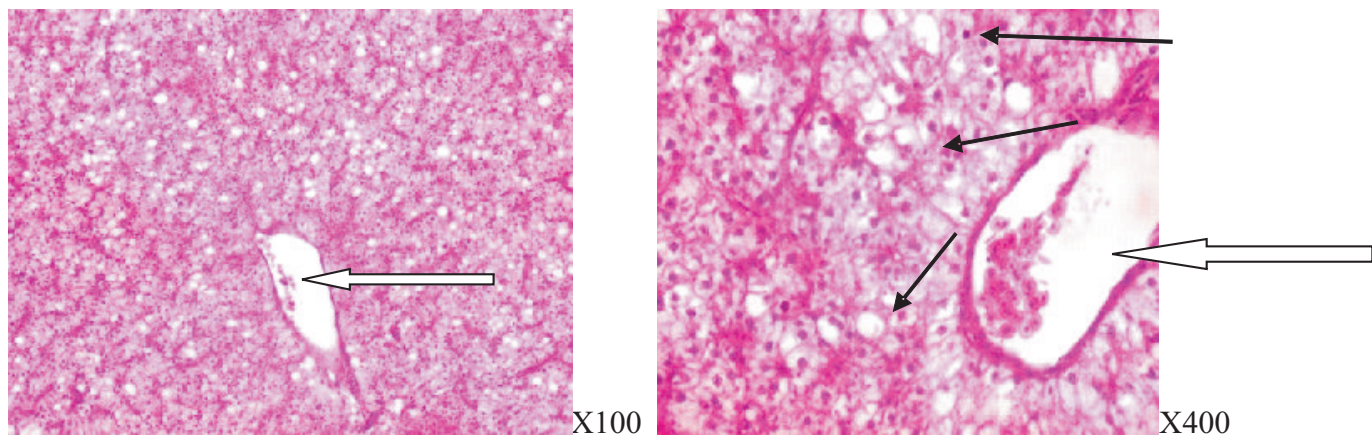

Figure 5: Histological section of liver of fish fed 100\% Morinda lucida leaves

The histological sections of the gills of fish fed varying levels of Morinda lucida leaves and the control are shown in Figures 6-10. Figure 6 reveals gills tissues with normal gill arch and the Lamellae or filament (black arrow) containing normal pilaster cells, chloride cells as well as normal epithelium and red cells (slender arrow). Normal cartilage of the arch is also seen (white arrow). Figure 7 shows normal gill arch and the Lamellae or filament (black arrow) containing normal pilaster cells, chloride cells as well as normal epithelium and red cells (slender arrow). Normal cartilage of the arch is also seen (white arrow). Figure 8 reveals that moderate to severe hemorrhage within the filament (black arrow). The pilaster cells and chloride cells show mild hyperplasia (slender arrow). Figure 9 indicates edematous filament (black arrow), some of which appear fused (red arrow) Normal cartilage of the arch is also seen (white arrow), the arch is mildly infiltrated by inflammatory cells (slender arrow). Figure 10 shows edematous filament (black arrow), some of which appear moderately infiltrated by inflammatory cells (slender arrow). Normal cartilage of the arch is also seen (white arrow).
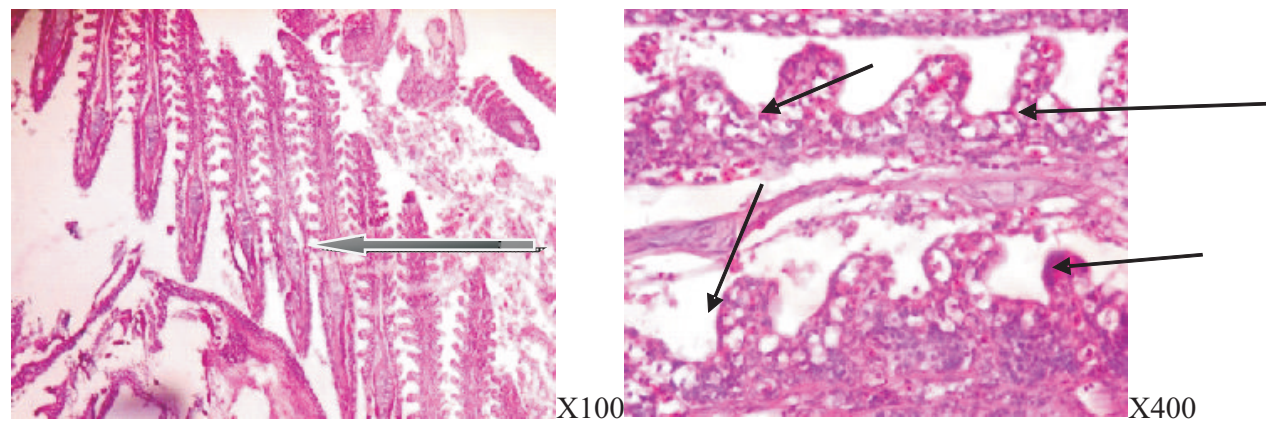

Figure 6: Histological section of kidney of fish fed control diet

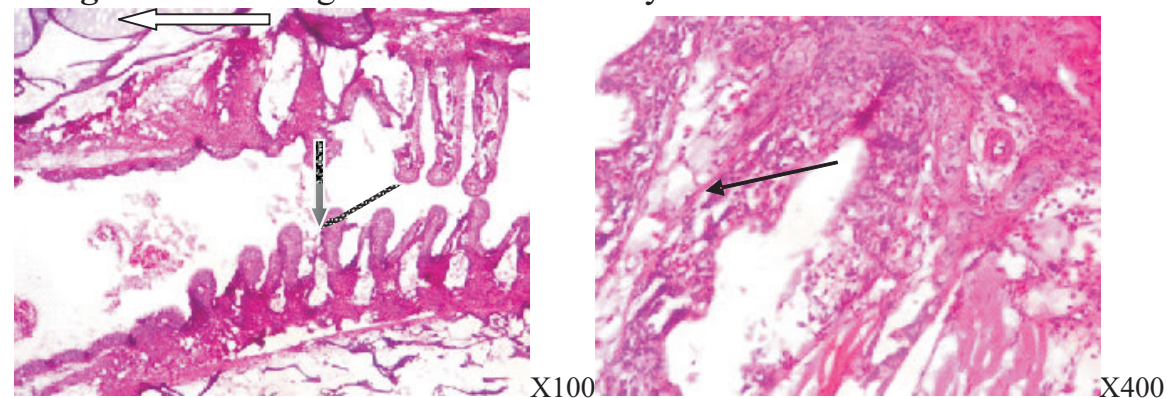

Figure 7: Histological section of gills of fish fed 25\% Morinda lucida leaves 


\section{Raimi,Oyelade and Alao}
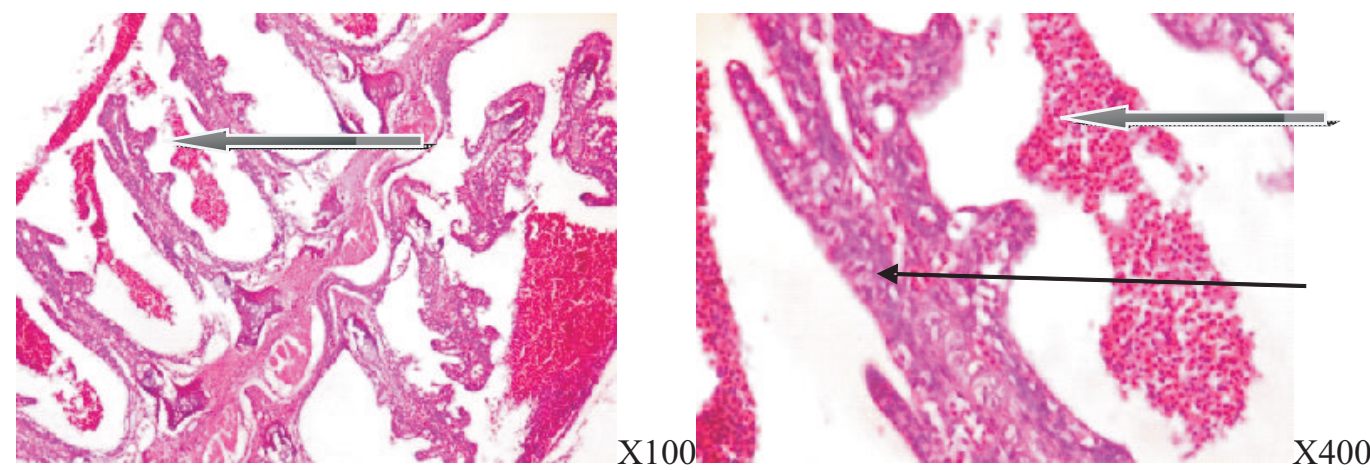

Figure 8: Histological section of gills of fish fed 50\% Morinda lucida leaves
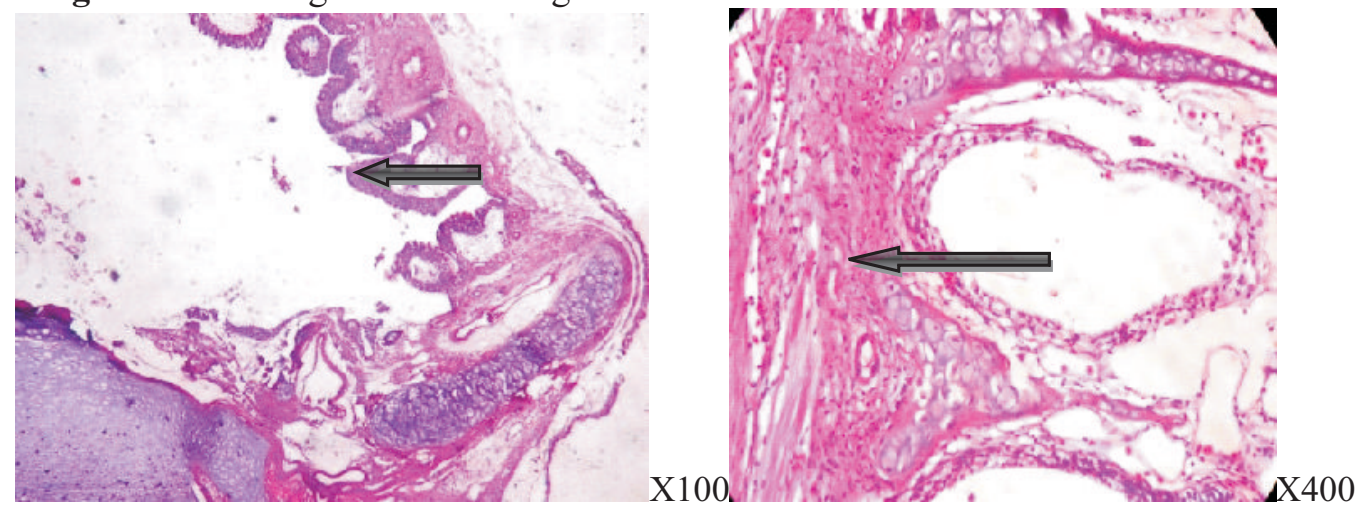

Figure 9: Histological section of gills of fish fed 75\% Morinda lucida leaves
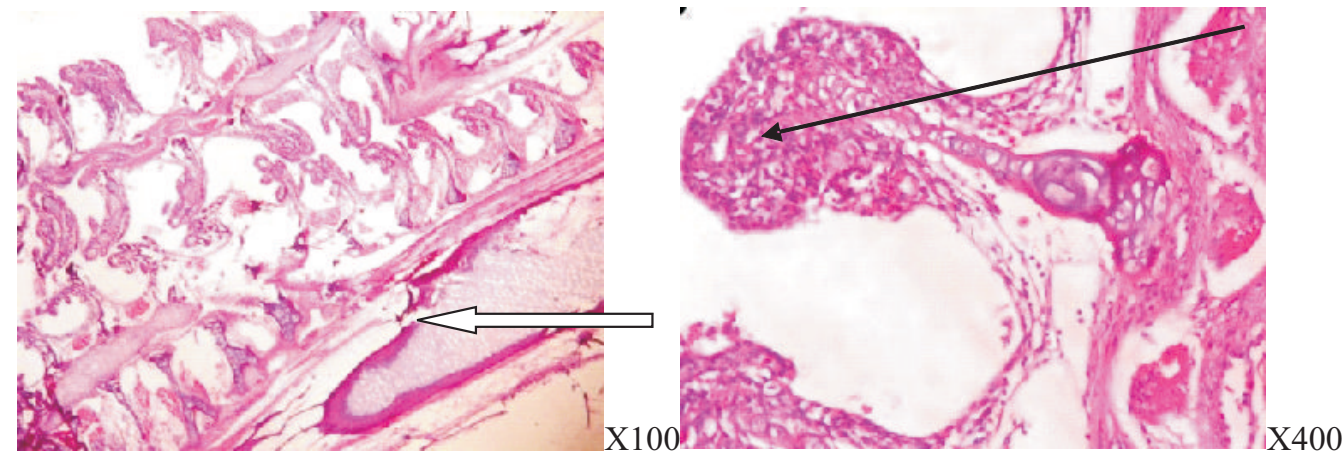

Figure 10: Histological section of gills of fish fed 100\% Morindalucida leaves

The histological sections of the small intestine of fish fed varying levels of Morindalucida leaves and the control are shown in Figures 11-15.Figure 11 reveals normal mucosal layer with normal glands without infilammation (slender arrow), the villi appear normal (white arrow), submucosal layer is normal (blue arrow)and circular muscle layer are normal (red arrow). Figure 12 shows normal mucosal layer with normal glands without infilammation (slender arrow), the villi appear normal (white arrow). submucosal layer is normal (blue arrow)and circular muscle layer are normal (red arrow).Figure 13 reveals normal mucosal layer with normal glands without infilammation (slender arrow), the villi appear normal (white arrow).the submucosal layer is moderately infitrated by inflammatory cells 


\section{Histology of juvenile African giant catfish (Clarias gariepinus)}

(blue arrow), and also involve the circular muscle layer (red arrow). Figure 14 indicates moderately sloughed/eroded mucosal layer (slender arrow), the villi appear moderately eroded (white arrow). submucosal layer is mildly infiltrated (blue arrow)and circular muscle layer are normal

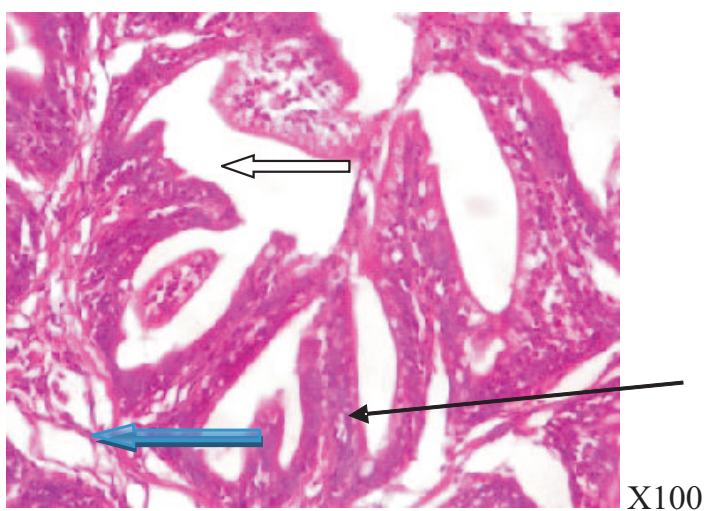

(red arrow).Figure 15 shows fairly preserved mucosal layer with focal area of necrosis (white arrow), the lamina propria is mildly infiltrated by inflammatory cells (slender arrow), the submucosal layer is normal (blue arrow) and circular muscle layer are normal (red arrow).

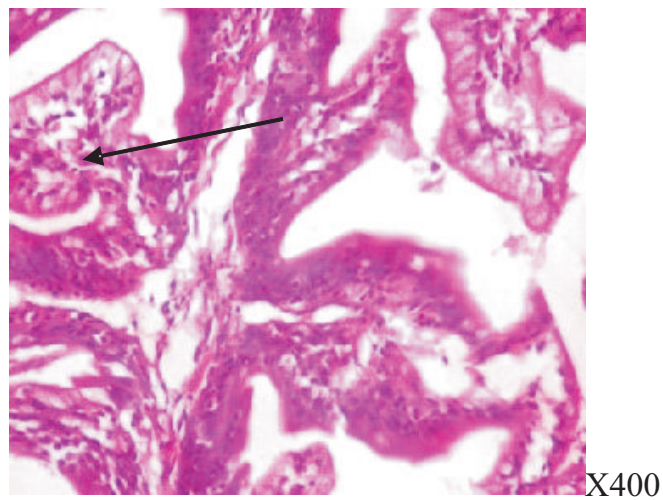

Figure 11: Histological section of small intestine of fish fed control diets
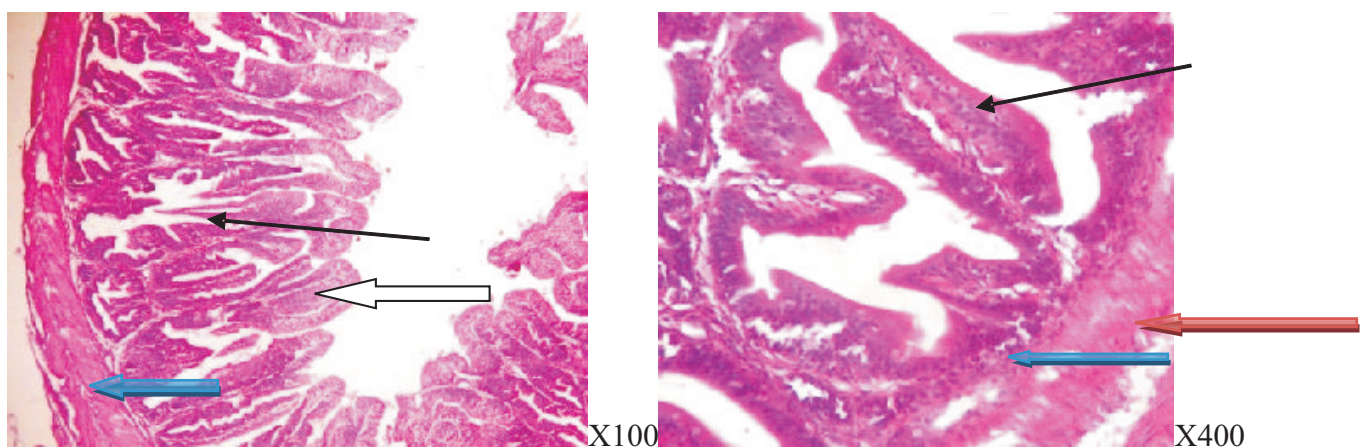

Figure 12: Histological section of small intestine of fish fed 25\% Morinda lucida leaves
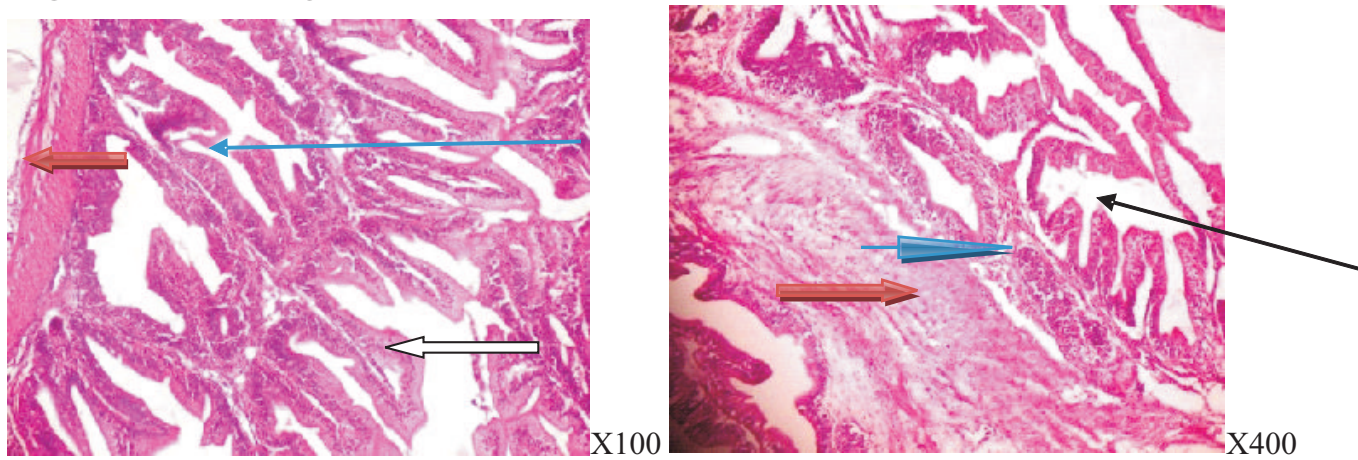

Figure 13: Histological section of small intestine of fish fed 50\% Morindalucida leaves 

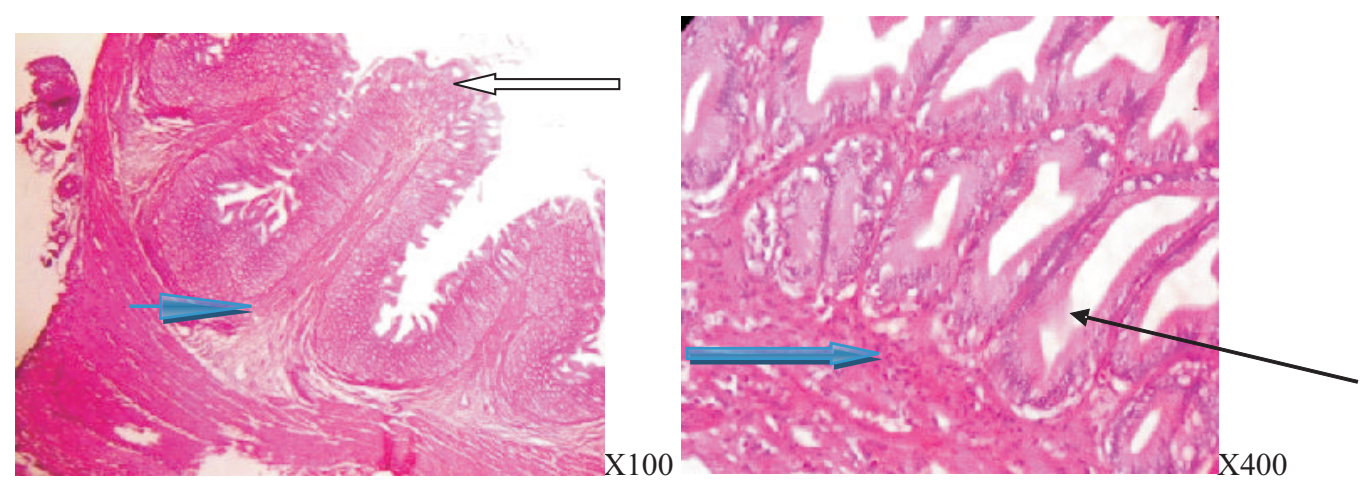

Figure 14: Histological section of small intestine of fish fed 75\% Morindalucida leaves
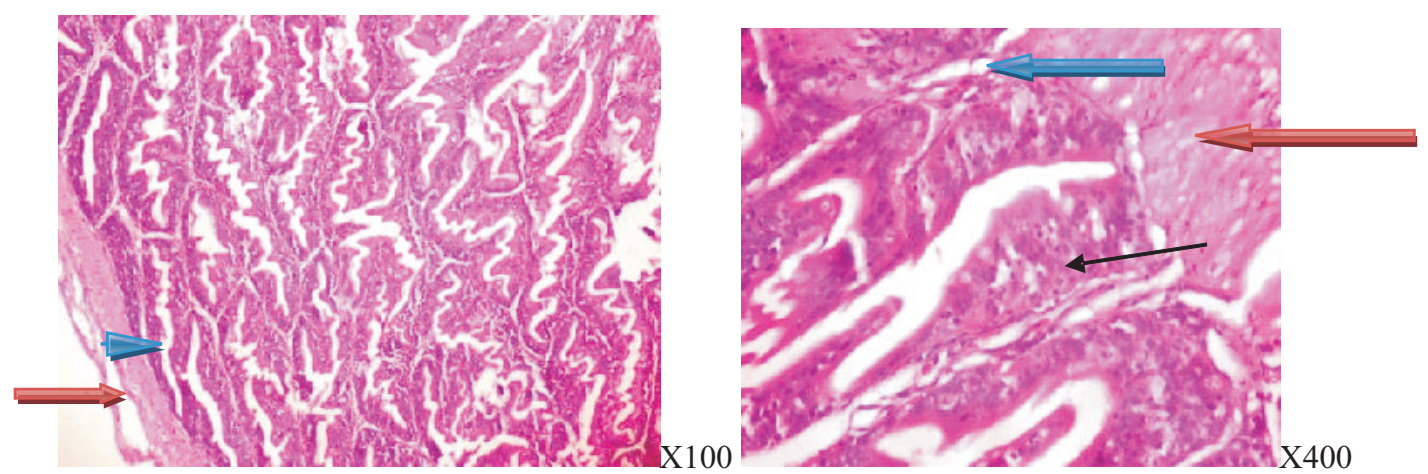

Figure 15: Histological section of small intestine of fish fed 100\% Morinda lucida leaves

\section{Discussion}

The histopathology of the liver of fish fed control diet showed that the liver was normal with mild glycogen change. The mild glycogen change might be attributed to the high fat content of catfishes. The histological sections of fish fed $25 \%$ to $50 \%$ Morinda lucida were also normal with necrosis; however, the liver of fish fed $75 \%$ Morinda lucida revealed marked and diffuse vacuolar fatty degeneration of the hepatocytes. This is in agreement with the report of Rapatsa and Moyo (2014) who observed vacuolation in fish livers fed $M$. oleifera diet treatment and the control. Also, histological sections of the liver of fish fed $75 \%$ to $100 \%$ indicated fish health was compromised at the highest dose. This is corroborated with the finding of Ashadeet al. (2014) who revealed that liver of fish fed $30 \%$ untreated ginger peel had a severe fatty
change.The presence of diffuse vacuolar degeneration of hepatocytes in fish fed varying levels of Morinda lucidaleave may be as a result of excessive work required by the fish's liver to get rid of the plant toxicant from its body during the process of detoxification. This is corroborated by the work of Bamidele et al. (2015) who revealed similar effect on the fish liver $M$. lucida inclusion (100\%) showed focal area of mild degeneration of the hepatocytes, most of the hepatocyte's cytoplasm appear vacuolated which is probably as a result of glycogen filling. In spite of similar protein and energy levels in the experimental diets, liver histology showed that $C$. gariepinus fed higher M. lucida (75\% and 100\%) levels had necrotic signs associated with poor nutritional status (Tusche et al., 2012). The malnutrition signs observed in $C$. gariepinusfed higher levels of $M$. lucida 


\section{Histology of juvenile African giant catfish (Clarias gariepinus)}

might be a consequence of the unavailability of protein and amino acids that have been bound with the tannins or have formed indigestible complexes with the polyphenols. As a result of the poor digestibility, a substantial portion of the essential dietary nutrients was not available to the fish and subsequently excreted. This explains the nutritional necrosis observed in the hepatocytes. The absence of visible changes in the histological sections of the gills of fish with varying dietary doses of $M$. lucida leaves could be as a result of tolerability of the dietary supplements to the fish gills. This was in agreement with the observation of Bamideleet al. (2015) who found similar result on the kidney of $C$. gariepinus fed $M$. oleifera seed meal. This is also corroborated by Daudu (2012) who observed no renal damage done in the broiler chickens fed ginger by product meal. Necrosis was observed in fish fed $75 \%$ and $100 \%$ M. lucida which is in line with the report of Agbebi et al. (2013) who observed tubular degeneration and necrosis of $C$. gariepinus fed $10 \mathrm{~g}$ ginger powder. This portends the fact that lowerconcentration of M. lucida leaves as the $25 \%$ to $50 \%$ dietary supplementation in the present study is tolerable by fish metabolic organs. Small intestine histology in C. gariepinus fed with $0 \% \mathrm{M}$. lucida inclusion showed normal mucosal layer with normal glands without infilammation, the villi appear normal. submucosal layer is normal and circular muscle layer are normal no recognizable changes were observed in the small intestine of the fish fed diet containing $25 \%$ of $M$. lucidacompared to the control diet $(0 \% \mathrm{M}$. lucida).Inclusion of $50 \%, M$. lucida in the diet showed the submucosal layer is moderately infitrated by inflammatory cells and also involve the circular muscle layer while 50\%, M. lucida inclusion showed moderately sloughed/eroded mucosal layer, the villi appear moderately eroded and submucosal layer is mildly infiltrated. The stomach cells were observed to have been massively destroyed in the fish fed diet containing 100\% Morinda lucida inclusion which showed fairly preserved mucosal layer with focal area of necrosis and the lamina propria is mildly infiltrated by inflammatory cells. Other authors have reported a widening of the central stroma within the mucosal folding, higher amounts of connective tissue; and an infiltration of inflammatory cells in the lamina propria (Refstie et al., 2000). However, work done on Tilapia rendalli (herbivorous fish) fed kikuyu and moringa diets indicated a higher ability of this fish to use plant-based diets than $C$. gariepinus, $T$. rendalli had lower levels of hepatocyte and intestine degradation(Hlophe and Moyo, 2014). Perhaps, this implied that fish fed diets on $75 \%$ and $100 \% \mathrm{M}$. lucida inclusion had severe liver, gills and stomach injury. The response in terms of histological profiles by the fish indicated that $75 \%$ and $100 \% M$. lucida inclusion can have negative effects on the fish as a sustainable feedstuff. Thus, the formulated diets up to $25 \%$ and $50 \% \mathrm{M}$. lucida inclusion were rich in nutrients, highly digestible, and could meet the nutrient requirements for growth and maintenance by $C$. gariepinus.

\section{Conclusion and recommendation}

The results from this work showed that $C$. gariepinus could tolerate up to $50 \%$ replacement level of soybean meal with Morinda lucida without any negative influence on the $C$. gariepinus. This provides information on the nutritional qualities of Morinda lucida as feedstuff for replacing high-cost soybean meal in practical diets of African catfish. The histopathological effect on liver, gills and stomachs showed that Morinda lucida can replace soybean meal up to $50 \%$ inclusion level with little or no damage to the fish liver, gills and stomachs. However, more 


\section{Raimi,Oyelade and Alao}

research should be carried out on the uses of Morinda lucida in order to reduce the antinutritional factors and better utilize the plant.

\section{References}

Adewoye, S. O., Fawole, O. O. and Owolabi, O. D. 2005. Toxicity of cassava waste Water effluent to AFR. Catfish Clariasgariepinus. Ethiop. Journal sci.28(7):189-194.

Adewumi, A. A. Olaleye, V. F. 2010. Catfish culture in Nigeria; progress, prospect and problems University of science and technology IfakiEkiti Nigeria. Afrj Agric. Res 6:1281-128.

Agbebi, O. T., Ilesanmi, A. I. and AbdulRaheem, I. 2013. Additive potentials of $Z$. officinale in the aflatoxin secreted in waste mould feed fed to Clariasgariepinus (Burchell, 1822). International Journal of Biological and Chemical Science, 7(1): 236-246. Histopathological effects of untreated ginger pee 1 (Zingiberofficinale) fish meal on the intestine tissue profiling of A f r i c a $n \quad c$ a $t$ - $f$ i s h (Clariasgariepinus). International Journal of Fisher-ies and Aquatic Studies 2: 95-98.

Avwioro, O.G. 2010. Histochemistry and tissues pathology, principle and techniques, claverianum press, Nigeria.

Bamidele, N. A.,Obasa, S. O.,Ikeiwenwe, N. B.,Abdulraheem, I., Adeoye, A.A. andOdebiyi, O . C . 2015. Effect of dried moringa (Moringaoleifera) seed mealbased diet on the growth, haematological, biochemical parameter and histopathology of African catfish, Clariasgariepinus fingerlings. International Journal of Fisheries and Aquatic Studies 2: 27-34.

Dauda, O. M. 2012. Effect of ginger byproduct meal supplementation with enzyme/palm oil on performance, blood chemistry and histopathology of broiler chickens. PhD Thesis, Ahmadu Bello University, Zaria, Nigeria. Pp. 205.

E L H a roun, E.R., God a, S ., Kabirchiowdhury, M.A. 2006. Effect of dietary probiotic biogenssupplementation as growth promoter on a growth performance and feed utilization of Nile tilapia Oreochromisniloticus $<\mathrm{L}>$. Aquao Res 37:1473-1480.

EL Haroun, E. R. 2007.improve growth rate and feed utilization in farmed African catfish Clariasgariepinus (burchell 1822) thought a growth performance biogen (R) supplementation. Jour $f i s h$ aqultscien 2: 319-327

Hlophe, S.N. and Moyo, N.A.G. 2014. A comparative study on the use of $P \quad e \quad n \quad n \quad i \quad s \quad e \quad t \quad u \quad m$ clandestinumandMoringaoleiferaa s protein sources in the diet of the herbivorous Tilapia rendalli. Aquaculture Intern., 22: 145-1262.

Levic, J.G., Sinisia, M.G.,Djuragic, O. andSlavica, S. 2008. Organic acid as alternative to antibiotics growth promoter. Achinazootechnica 11:15-17.

Miller, G. G., Sweet, L. I., Adams, J. V., Omann, G. M., Passino-reader, D. R. and Meier, P.G. 2002: Invitro toxicity and interactions of environmental contaminants (Arochlor 1254 and mercury) and immunomodulatory agents (lipopolysaccharide and cortisol) on thymocytes from lake trout (Salvelinusnamaycush). Fish \& Shellfish Immunology, 13(1): 11- 
26.

Morah, F.N.I., Ekanem, P. and Ashipu, L.B. 2005: Effect of Mormordicacharanti leaf on water parameters and survive rate of Clariasgariepinus. International journal of current research in life science $<$ in press $>$.

Oduola, T., Bello, I., Adeosun, G., Ademosun, A.W., Raheem, G. and Avwioro, G. 2010. Hepatotoxicity and nephrotoxicity evaluation in Wistar albino rats exposed to Morinda lucida leaf extract. North Am. J. Med. Sci., 2: 230-233.

Oyedapo, F. and Akinduyite, I. 2011. Acute toxicity of aqueous Morinda lucida leaf extract to Nile tilapia Oreochiomisniloticus (Linnaeus 1857). Proceeding of the ninth international symposium on tilapia in aquaculture Shanghai, China. April 22nd-24th, 52-59.
Rapatsa, M. M. and Moyo, N. A. G. 2014. Effect of Moringaoleifera on the histology, haematology and growth of Oreochromismossambicus in aquadams fertilized with chicken manure in South Africa. African Journal of Aquatic Science, 39(3): 295-303

Refstie, S., Korsǿen, J., Storebakken, T., Baeverfjord, G., Lein, I. and Roem, A.J. 2000.Differing nutritional responses to dietary soybean meal in rainbow trout (Oncorhynchus mykiss) and Atlantic salmon (Salmosalar). Aquaculture, 190: 49-63.

Tseng, W. Y. and Chan, K. L. 1982. The reproductive biology of the rabbit fish in Hongkong. $J$. word MariculSoc 13(1-4): 313-321.

Tusche, K., Arning, S., Wuertz, S., Susenbeth, A. and Schulz, C. 2012. Wheat gluten and potato protein concentrate-Promising protein sources for organic farming o f r a i n b ow trou t (Oncorhynchusmykiss). Aquaculture, 349: 120-125.

Received: $14^{\text {th }}$ July, 2021

Accepted: $10^{\text {th }}$ December, 2021 